Vol. 6, No. 2, 2019

https://doi.org/10.23939/eem2019.02.012

UDC 681.5:519.24

JEL Classification Code F 23, G32, L2

I. Yaremko,

Lviv Polytechnic National University, Ukraine, Doctor, Professor

E-mail: I.Yaremko@i.ua

ORCID: 0000-0003-4624-7634

I. Kantsir,

Lviv Polytechnic National University, Ukraine, Ph.D, Associate Professor

E-mail: kanthir_02@ukr.net

ORCID: 0000-0002-1259-0381

M. Plekan,

Lviv Polytechnic National University, Ukraine, Ph.D, Associate Professor E-mail: marysiaplekan@gmail.com

ORCID: 0000-0003-2715-1290

\title{
FINANCIAL MANAGEMENT OF THE ENTERPRISE ECONOMIC POTENTIAL
}

\begin{abstract}
Drawbacks of the basic principles of management of financial and economic potential in the national platform are defined. The mechanism of approximation of modern concepts of financial management of the economic potential is specified and proved. The analysis of principles and tools in the systems of financial management of the intangible potential (intangible assets, brand, customer equity, inner generated goodwill) is carried out and possibilities of their implementation in Ukrainian enterprises are assessed. Author's opinion regarding the key objects of the financial management of business reputation, intangible assets, and market constituent of the aggregate capital of the enterprises of the national economy is presented, algorithms to measure the intangible constituent of the enterprise value for administrative purposes have been formulated.

Key words: financial management, economic potential, value estimation, intangible capital, financial tools, foreign experience, adaptation methods.
\end{abstract}

\section{Introduction}

The state of the modern Ukrainian economy and pre-conditions of its development are complex, underspecified, and have a number of peculiarities in comparison to the economies of the developed countries. Transition of national economic entities to the market relations is of complex (unconventional) nature predefined, first of all, by the absence of the relevant management system and actually insufficient training of managers that lacked qualification to provide efficient management of the financial and economic potential. Consequently, enterprises experienced a production decline, that resulted in the economic downfall and extremely low level of investment attractiveness.

Enterprise management, based on the cost specifications of its economic resources, accrual of their cost (capitalization), is made actual by modern dynamic processes of global economy growth, capital mobility, and informational requirements of the institutional investors.

Regarding the investment attractiveness (costs), relevance and problematic nature of capitalization of domestic enterprises of machinebuilding complex is decisive, as disposition of 


\section{Financial management of the enterprise economic potential}

interconnection of their capitalization with creation of conditions of their ability to functioning possibilities in general is obvious enough.

Principles of corporate management of the Ukrainian enterprises and determination of efficiency of their functioning must be based on the implementation of generally accepted concepts of the market system that meet the requirements of investment companies, funds, and financial institutions. Taking into account the distorted cost of the Ukrainian commercialized economic entities made up due to the application of the excessively simplified methodology of cost determination of the integral property complexes at their formation during the processes of denationalization and privatization. Thus, it is essential to solve the problem of finding relevant financially-analytical and evaluation instruments for the information supply management by the criterion of economic added value creation used in the international business.

The growth of capitalization of companies with a high intellectual component («new economy») stipulated numerous researches of evaluation of capital cost and its constituents. Basically new conceptual principles of aggregating of showings and indicators are the results of these consequent researches to provide the financial management system with the capital cost. Alongside the traditional assets, non-financial indicators were obligatory introduced into the management systems of the capital cost to diagnose the influence of intellectual component on the alteration of the capital cost, that is why "development of theoretical and methodological principles of cost estimation is considered one of the foremost tasks in the theory of finances today" [1, p. 18].

Additionally, it is possible to give an example of the German Code of Corporate Governance, that indicates that "the aim of a company management is a continuous increase of its value" [2]. By means of the capitalization index Thomson Financial Data Base distinguished 800 biggest corporations, which share is $33 \%$ in the world GDP.

Structural changes in the global economy, a change of the criterion regarding the components value of the financial and economic potential (assets and capital) of an enterprise, a new market outlook at the business value of modern economic units and their investment attractiveness require the revision of the old developed stereotypes of the administrative thinking in the national theory and practice and transition to the new forms and methods of the financial management system, all these determine the relevance of the researches of this subject.

\section{Analysis of recent researches and publications, problem statement}

Different aspects of improvement of the existent concepts of cost management of the joined economic resources of an enterprise and insurance of efficiency of economic unit operation by the criteria of the created value are found in the works of foreign scientists and worked out by the companies of the developed economies. Development of the reliable set of tools for insuring effective financial capital management and application of financial instruments in these processes is the subject of the scientific programs and researches of scientific and academic establishments and specific organizations (firms).

Significant contribution to the methodology of the financial management systems design with a set of proper tools in the development of cost paradigm of the enterprise management was made by foreign scientists, R. Braley and S. Myers stated that: "Value is usually the criterion of success. The secret of successful financial management lies in the value growth" [3, p. 3]; P. Doyle mentioned: "In recent years the task of shareholder value increase is considered to be the foremost by the managers of the increasing number of large companies" [4, p. 16]; M. Scott wrote: "In recent years the primary managers' objective is to increase the value of ones' own (or shareholder) firm capital" [5, p. 25]; T. Kouplend, T. Koller, D. Murin pointed out that: "Cost maximization for shareholders is or must be the primary objective of all enterprises" [6, p. 25].

Regarding the dynamic change of key influence factors on the enterprise cost and taking into account the specific features of the business branch and peculiarities of the national economy, the defined process did not acquire the final scientific generalization, agreed scientific and theoretical construction in the systems of cost evaluation of the economic resources for the cost management of a machine-building enterprise. 


\section{Yaremko, I. Kantsir, M. Plekan}

Considerable economic transformations of the modern global economic environment require clarification of the developed principal approaches to the cost evaluation of the enterprise capital and their use in the management process.

Important approaches to solve this issue were offered by Dyson, Farr and Hollis having designed the system with two components - "Consumer Value Model" and "Brand Dynamics Pyramid". It is worthwhile to note the model BV\&A - brand valuation \& analysis. This methodology of the Russian company V-Ratio, on the basis of evaluations and analysis, is aimed to define the cost factors created by the brand by means of additional sales. These particular sales are further used to calculate the brand value that makes this methodology similar to the concept of Brand Equity, i.e. brand capital (brand assets).

A competent specialist in the field of administrative technologies, including the management of the processes of value enhancement of companies and business, A. Damodaran proves that «basic rules and concepts of cost management are identical in any case regardless the company that is evaluated and the market it operates on» [7].

Financial analysts and consultants of McKinsey Co. have the similar view, who specify that although "many examples are taken from the American reality, fundamental principles of value estimation and described methods of this estimation are acceptable in any country" [6, p. 18]. Notwithstanding this fact, the possibilities to use the designed foreign systems of financial management directed towards the management of the processes of the assets value enhancement with certain adjustments to the peculiarities of the national economy are not as unambiguous as it is mainly presented in national publications.

Despite the generalized grounds of expediency to rely on the methods generally accepted in the international practice, many researchers point out the complexity to use the set of financial instruments traditional for the developed economies, as well as that "under the conditions in Ukraine the traditional methods of the cost estimation underestimate the potential of Ukrainian business" [8, p. 229].

\section{Purpose and tasks of the research.}

The purpose of the research is theoretical generalization and practical analysis of the world experience as to organization of financial management of resources of modern market economy units with the aim of enhancement of their value.

It is necessary to find ways and approaches to improve already existing in the Ukrainian theory and practice theoretical and methodological aspects of the financial management system on the basis of customization of foreign experience, in particular the development of scientifically-theoretical principles of the enterprise management on the basis of value criteria giving reasons for the conceptual basis of the economic evaluation system of the cost parameters of an economic unit, corresponding to the terms of the national economy.

The purpose of the research and reaching its goals determine to set and solve the following tasks:

- to disclose the economic content, fundamental and conceptual principles of financial management of economic resources value in the general system of the enterprise corporate management in the modern economy;

- to generalize the content essence and operating practice of cost values application as a criterion to determine the functioning efficiency of an enterprise and a corporate management system;

- to summarize the international practice and to find out main contradictions of the developed principles of the financial management of the components of intellectual resources and intangible capital of modern enterprises and approaches to assess synergy potential of the economic systems;

- to develop the conceptual principles and methodical provisions for estimation of informativeintellectual resources and intangible assets as inner goodwill of the company for financial management purposes.

Only certain aspects of financial management of well-known international corporations are under consideration in modern Ukrainian economic literature. The issue of financial management, aimed at assets and capital value enhancement, remains understudied, as it was not fully and systematically summarized, including the possibilities to customize foreign experience to Ukrainian practice. Scientific and practical researches mainly concern general administrative aspects regarding the customization of the national business to the conditions of informational intellectual economy, modern markets of capital, goods, and investment. 


\section{Financial management of the enterprise economic potential}

However, certain issues concerning the reformation of financial management aimed at creation of flexible and reasonable systems of financial management of the existing potential for native practice were left out of consideration, They would allow Ukrainian business enterprises to obtain certain position on the international markets.

General scientific methods are used to carry out the research such as methods of theoretical analysis and estimation of the real capitalization of the national companies together with the methods of comparable criteria analysis used in the world practice for market enterprises.

\section{Research of the model of the value estimation of the economic potential management of the company}

Current economic processes and value relations between different entities and concerned parties put forward a number of additional problematic issues, related both to the processes of evaluation of the structured economic resources of modern enterprises, created added cost during their operation and to the set of tools to support management decisions for their value creation. This issue is particularly current for the enterprises of the national economy that adapt to the developed principles and provisions of business organization within the global market system: "Sustainability of corporation is provided by the timely adjustment (customization) of the development goals, change of functions of an organization to new market conditions" $[9$, p. 55].

Development of the value aimed for the management system occurs on the basis of creation of new methodological instruments or adaptation of the main provisions of the fundamental theories (paradigms) of these managerial systems or models. The "Welfare of the Firm Theory" provides the construction of integral models of the economic activity, where any managerial decision is considered within its influence on the market value of a firm [10, p. 135].

The requirement of objective and at the same time transparent model of the value estimation, changes of the amount of the private property of the economic entity is marked by the approaches of the international network of corporate management to the principles of the Organization of Economic
Cooperation and Development (Statement on Global Corporate Governance Principles), which underline that "the aim is to facilitate the international dialogue concerning the ways of strengthening of companies accountability to their owners in order to increase the equity value" [11].

Global share voting principles confirm the credibility of conceptual principles of the value corporate management, according to which "maximization of the market value of an enterprise and business organization provides the growth of the shareholders' benefits and equity value".

Taking into account the complexity of the diversified factors and aspects that influence the market value of the enterprise capital, modern systems of economic evaluation and management of the processes of value formation of the economic entity are based on the vast conglomerate of interdisciplinary basis - management concepts, conceptual and methodological principles of evaluation, principles of investment indexes formation on the basis of aggregating the standardized indexes of the financial statements and cash flow discounting models, capital and profit theories, evaluation methods of fixed and investment assets, that are taken into consideration in methodological basis of systems of different formats and models of the value estimation.

The company management concept based on the criteria of the value growth of the business is the integrated concept based on the fundamental results of the theory of corporate finances and methods of strategic management [12, p. 135].

It is believed that, according to the fundamental principles and developed principles of the value paradigm, a corporate management must generate decisions aimed at the key objects and factors that lead to the increase of the shareholder value. This theoretical ground of corporate mission aimed at maximization of the shareholder equity, as the primary goal of any company, is unquestionably balanced enough with principles of the social oriented market economy and socially responsible business. However, the needs of company's capital allocation do not always coincide with the shareholders' requirements for many reasons, that is why, in many cases, it is considered that "corporations are not run to maximize the shareholders' welfare, - actually, the shareholder 


\section{Yaremko, I. Kantsir, M. Plekan}

value of many companies keeps falling year after year" $[13$, p. 4$]$.

Risk management is a hidden form of the equity value decrease or factors that put pressure on its value profile that balances on the verge of the dynamic accumulation of problem assets - formation of "problematic", "bad", "toxic" company's assets (accumulation of expenses of future periods that were not deducted on time); using of the capital for excessive expenditures "to gain business reputation" or for representative expenses (market factors of capital value growth) that in many cases cannot be sufficiently proved, etc. However, information about such economic activity is regarded to stimulate the growth of market value of the company (shares rate).

In practice, the administrative body of an enterprise, balancing on a very thin verge, must solve a formidable task - to generate profit and capitalization of an enterprise at the same time: "Precisely because of impossibility to make a single estimation of the company operation efficiency as in a strategic aspect so in an operative management, the BSC concept cannot be regarded as the universal one" [14, p. 67].

Fundamentalism of the theory of efficiency is usually regarded through the formation of the integral (synthetic) index of the enterprise operation efficiency that, from one side, estimates objectively the results of its completed activity, and from the other - characterizes the created potential of an enterprise.

One of the related dissertation researches [15, p. 112] presents the generalized structure, offered by native and foreign scientists, of including value components of the financial state $-19,64 \%$, business risk-taking $-14,29 \%$, the business scale $12,50 \%$, brand value $-12,50 \%$, organizational and administrative components - 8,93\%, market conditions $-7,14 \%$, competitiveness $-7,14 \%$, scientific and technical potential $-7,14 \%$, macroenvironment $-5,36 \%$, microenvironments $5,36 \% "$.

Working out of a summarizing (synthetic) efficiency index, in our opinion, the system of indexes that reflect the level of reserves and the fixed capital insurance must also be taken into account, that it is especially important under the conditions of unsteady environment. For sure, these indicative components will hold the main position in the methodological basis of the economic evaluation systems of the value of the economic entities in the "post-crisis model of business". Application of the reserve indicator in the evaluation models is not common.

In the modern market economy, characterized by a number of uncertainty factors, the problem of establishing objective capital value to provide the management with the processes of its raising, allocation, application and capitalization of assets is a cute one. For the management purposes, it is suggested to concentrate on the objects shown in the Fig. 1 (financial potential, innovative potential, productive potential, potential of the fixed and circulating funds, etc.).

The capital value, besides being the measure that characterizes the market value of an enterprise in a current period, is specified, due to its dynamics, to possess the characteristics of the investment resource, a purchase-sale object, property and accumulated value, production factor and an object of management, risk carrier, and other properties.

Methodological basis of the value characteristic systems of the intangible component of the capital of the operating enterprise in the existent systems is based on the indexes of the "excess income", "excess profits" or additional money flows. These approaches are unacceptable because it is impossible to use any of the offered indexes as constant ones to calculate the value of intangible economic resources of the national machine-building enterprises.

A number of objective reasons makes it impossible to assess value of the intangible potential of a machine-building enterprise applying the method of differences between the market value of the business in general and the identified assets.

Thus, we assume, that any enterprise capable to operate in the modern economy owns certain "goodwill". Number of factors makes it impossible to use profitable concepts to assess the intangible component of the capital of the national enterprises, because of their value incredibility to the financial indexes. 


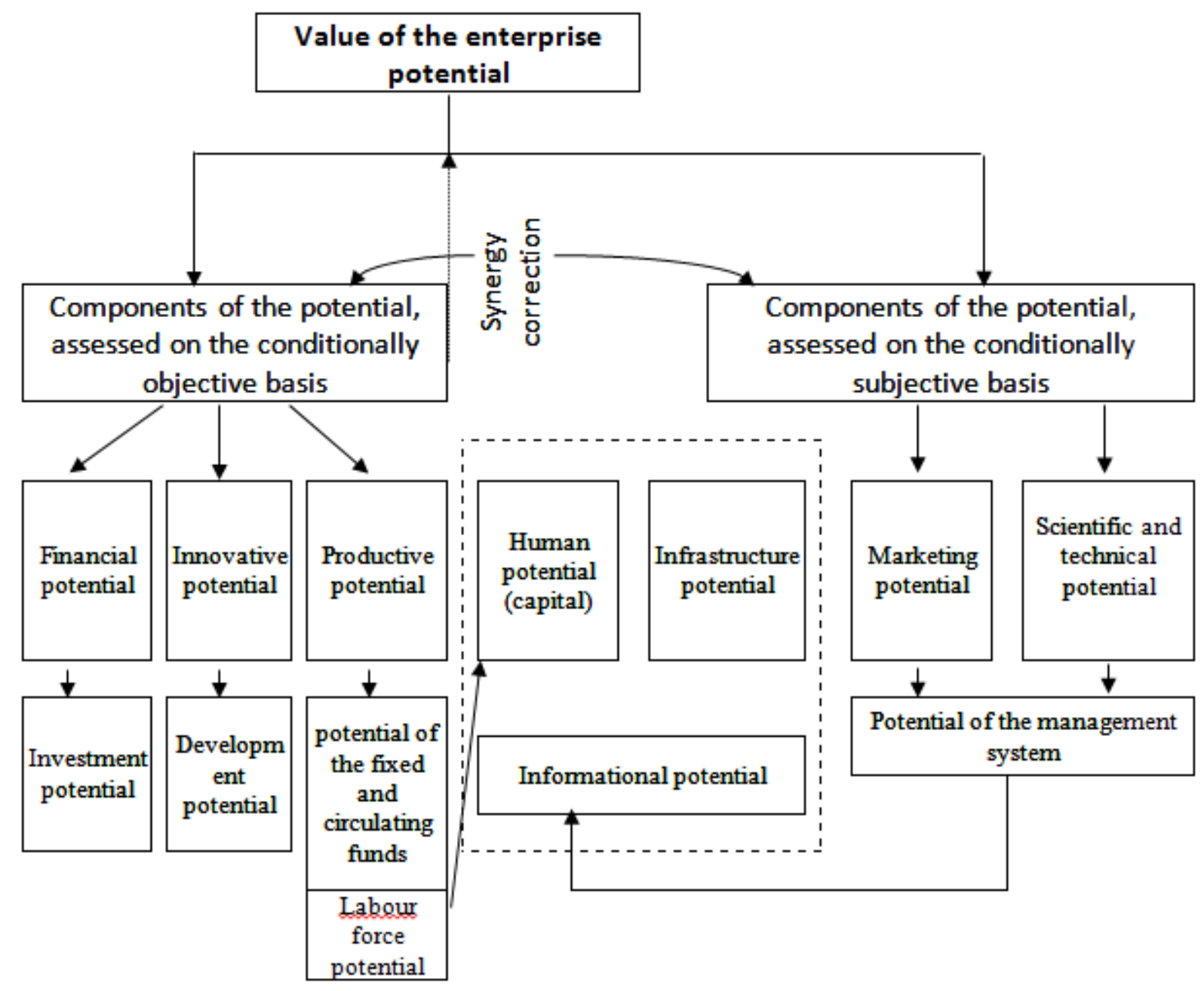

Fig. 1. Objects in the financial management system of the enterprise potential

\section{Working out of the methodology of evaluation and management of the intangible capital value of the machine-building enterprises}

A certain type of an intangible economic resource has different value significance in the capital of different enterprises, depending on many factors of their functioning. That is why, the approach that evaluates intangible resources in connection with the tangible ones in a more objective way is chosen. Productive combination of indexes, that characterizes the value of the actually functioning infrastructural, intellectual, human and other intangible components, determines the amount of their productive energy (cost effectiveness) in the operating capital, and together with the tangible and financial capital - additional synergy force and productive efficiency of the enterprise potential ("ideal capital").
It is suggested to apply general principles of evaluation of the intangible capital value and management of the intangible component value of the machine-building enterprise, to conduct monitoring and diagnostics of the value of the structural components of intangible factors using the designed approach shown in Fig. 2.

By the worked out methodology, the value of the "traditional" (verified) intangible assets (K1) is determined by their paid (residual) cost. The value of the innovative component of the intangible potential is defined by the inventory taking data grounded on the formulated methodological provisions that are based on concept of the not-shown assets with the use of the elements of aggregate, norm-calculation and analogue approaches with application of the correcting procedures of "the method of assets utility reduction". 


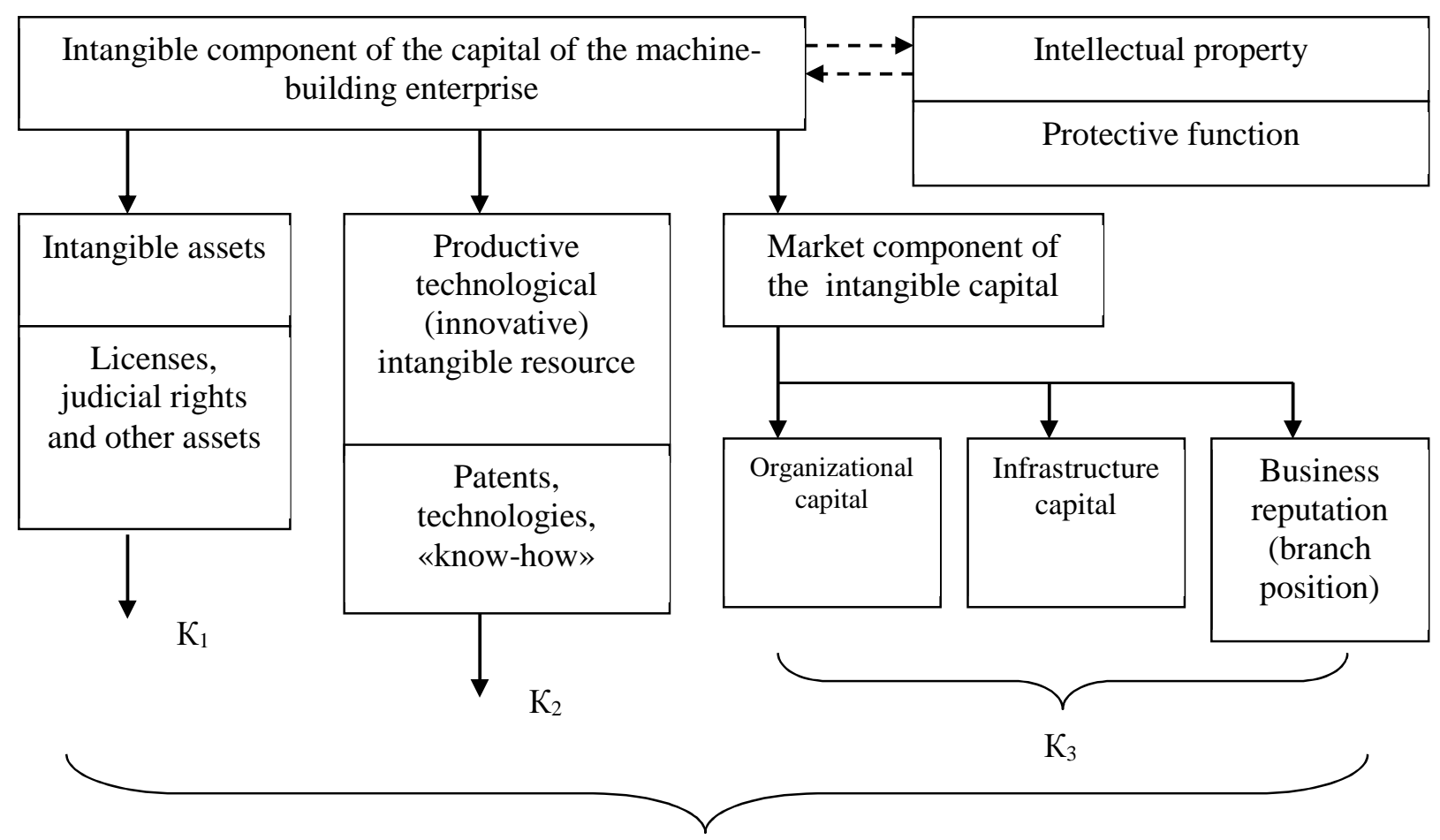

Inner firm goodwill («ideal capital of the company»)

Fig. 2. General scheme of evaluation and management of the intangible capital value of the machine-building enterprise

The results of scientific and technical production evaluation as objects of intellectual property are supported by the elements of Borda's procedures (ranked alternatives), Yang (successive comparisons), and also Kemeny median (group judgement).

Evaluation of the market constituent of the intangible capital of the Ukrainian enterprises is more reasonable to conduct with the observance of maximum limit (norms) of their cost to the total value of actual economic resources, set by the regulators of capital markets by the branches of the economy.

The value of traditional intangible assets (K1) is determined by their residual value. The scope of the innovative constituent of intangible asset (K2) is found on the basis of the adapted algorithms, adhering to the methodological provisions, for example, provided in the letter of the Ministry of Finance of Ukraine "Regarding the initial cost of an object of the intellectual property as an intangible asset", International and national standards. Value estimation is conducted on the basis of expert concordances and inventory taking with the further application of the correcting procedures by the "method of the assets utility reduction". Taking into account little competitiveness of the Ukrainian enterprises, small amounts of cash allocated for the researches and developments, evaluation of their market constituent requires maximum limit off the total cost of the actual economic resources by the branches of the economy, worked out by the regulators of the capital markets. For basic machinebuilding enterprises we offer index 0,2. Formula of the total value evaluation of intangible resources (intangible capital) for machine-building enterprises is the following:

$$
\begin{gathered}
K_{H}=K_{1}(H a)+K_{2}+ \\
+K_{3}\left(\sum K_{3} \leq 0,2 \text { Bcчa }\right),
\end{gathered}
$$

where $\mathrm{K}_{\mathrm{H}}-$ is the total value of the intangible constituent of the enterprise capital; $\mathrm{K}_{1}(\mathrm{Ha})-$ intangible assets - paid (residual) cost of their purchase; $\mathrm{K}_{2}$ - assessed research and engineering works, projects, perspective developments, engineering samples, administrative processes as an intellectual resource; $K_{3}$ - is a market constituent of the intangible capital of an enterprise; Всча - is a value (fair value) of the corrected net assets of an enterprise. 


\section{Financial management of the enterprise economic potential}

By the results of the research we put forward the categorical statement, that until the financial statement (balance) will not include the index of intellectual-informative capital available on the enterprise, aggregated on the formalized methodological basis, we cannot speak of any standardized (acceptable) procedure of their representation, - neither through different evaluation systems nor through their representation by the reports on intellectual capital.

The analysis of market capitalization of the leading hi-tech companies proved that factors of intangible nature form their value on $70-90 \%$, which are not recorded in the system of accounting and financial statements.

Some economists suggest to solve this issue through traditional financial statements and reports on intellectual capital, meaning to get "certain synergy" out of this. Some superficial grounds are theoretically put forward, that such generalizations give an opportunity to explain discrepancies between a balance value and market capitalization of the companies.

Practice testifies, opposite to these theoretical suggestions, that external users (and the managerial office itself), without the specified methodology on the verified intellectual capital, get only the general characteristics about the whole intellectual capital. It should be noted, that investors' feedback on the reports on intellectual capital is not as unambiguous as it is described in the literature, especially because of the excessive overstatement of the expectation effect from the intangible capital by the companies.

Structural capital includes all company's infrastructure - informational technologies, working processes, communication systems, informative resources, etc. Innovative part of the structural capital comprises intellectual property (patents, license agreements), as well as the resource, that is difficult to define precisely, that will determine the value of a company to a greater extant in future (scientific and technical researches and developments, know-how, ideas, inventing activity).

A client ("brand") equity is a value that reflects the relations with customers, such as brand name, advantages of customers, lists of clients, well-known trademarks, etc. However, this "value as an economic category, unlike the cost, cannot be shown in absolute indexes directly. Thus, the methodology of estimation of the company's value must be based on the application of the comparative approach" [14, p. 71].

General estimation of the company's value and management of the key factors value also include the estimation of such hypothetical notion as the brand value. The issue of evaluation of the brand value attracted more attention in the $80^{\text {th }}$ of the XX c., when theorists and practitioners of marketing began to develop the evaluation systems of brand value to create competitive advantages, using traditional ideas about intangible assets as the basis maximizing their value in different ways (for example, providing data about their availability in a statement of Value Reporting).

From the financial point of view, the brand value must be expressed by a certain figure (e.g., the result of the professional estimation). The value of this type of the resource potential is required at mergers and takeovers, the brand itself can become the object of purchase or sale, etc.

The initial price, control, stimuli (moral hazard), and the final price are the contract drivers of price setting [16, p. 17].

In investment projects the brand value can be included into the initial capital of the launched company and used as a mortgage. Marketing specialists apply the brand "value" as an instrument of investment management in marketing. Mainly indexes, that characterize brand market positions, forecast sales, etc., are used as output data for calculations, that forms its value estimation. However, the "brand value cannot be measured, but can be evaluated. As a result, opportunities for brand management appear".

The latest management concepts appear at the borderline of financial and productive management, logistic and marketing, examining of operations and mathematical statistics [17, p. 37].

Weighted average cost of capital is calculated by the formulas:

$$
W A C C=k_{u}-k_{b} \cdot\left(\frac{B}{B+S}\right) \cdot T,
$$

where $k_{u}$ - is the expenses on the owner's equity; $k_{b}$ - expenses on the loan capital; $T$ - marginal tax rate on the interest expenses; $B$ - market value of the loan; $S$ - market value of the owner's equity. 
In the most general view, expenses on capital are calculated by the formula:

$$
\begin{aligned}
W A C C= & k_{b} \cdot(1-T) \cdot \frac{B}{B+S}+ \\
& +k_{s} \cdot \frac{S}{B+S}
\end{aligned}
$$

where $k_{b}$ - expenses on the loan capital, that correspond to the long-term interest rate; $k_{s}-$ expenses on the owner's equity without tax burden; $T$ - marginal tax rate; $B$ - market value of the loan; $S$ - market value of the owner's equity.

Regarding the mentioned above notions, Weighted Average Cost of Capital - WACC is calculated by the formula with the defined component of the cost of the raised capital:

$$
W A C C=(E / V) \times r_{e}+(D / V)-\left(1-t_{x}\right) \times r_{d},
$$

where $E / V$ - is the share of the market value of the shareholder capital of the total capital; $D / V$ - a share of the raised capital in the market value of the total capital; $r_{e}$ - the cost of the shareholder capital; $t_{x}-$ tax rate; $r_{d}-$ the cost of the raised capital.

An instrument suitable to estimate the advantage of capital investment in securities is the traditional fundamental analysis that studies the information of potential investing object. The algorithm to estimate future dividend flows, that are the foremost investors' interest, is offered for such purposes. Payment and sum of dividends of ordinary shares are not fixed, and during the calculation their increase is possible with $g$ rate per year. In this case, the investment value of a share is:

$$
P_{0}=\sum_{t=1}^{N} \frac{D_{0}(1+g)^{t}}{(1+R R R)^{t}},
$$

where $P_{0}$ - investment value of an ordinary share; $\mathrm{N}$ - number of periods the investment is made for; $D_{0}$ - amount of dividends for the last period before the investment; RRR - required rate of return.

\section{Discussion of the research results in the context of improvement of the concept of the non-shown assets and the method of the assets utility reduction}

For the national economy enterprises, it is the most important task to work out relevant principles and methodological bases for evaluation of intangible assets and intellectual constituent of capital (inner brand goodwill ("ideal capital of a company"), that are based on the improved concept of the non-shown assets and on the method of the assets utility reduction using the elements of aggregate, norm calculation, and analogue methods.

The offered approach assumes inventory expert estimation of the innovative-technological assets available in the company and verification of business reputation on a branch market segment, calculated in relation to the value of the net corrected assets (economic potential) of an enterprise that allows the formalized indexes to represent the value of the enterprise business in an extended way.

\section{Conclusions}

1. Significant and understudied issue of evaluation of available economic resources and indexes of additional cost for introduction and further efficient use of the value-oriented paradigm of management, the necessity of its solving, taking into account the peculiarity of the economy of Ukraine, using fundamental and conceptual principles and developed approaches to the cost management in the world practice, prove relevance and importance of scientific researches of this subject matter.

There is a necessity to formulate acceptable content of the methodological principles and methodology of the objective evaluation of the economic potential of economic units and to define additional (lost) cost of the employed capital of the enterprise in the national economy science. For management purposes, it is suggested to focus on financial potential, innovative potential, productive potential, and potential of the fixed and circulating funds.

2. Appropriateness of application of the methodology of intangible assets in relation with tangible ones is proved. Productive combination of indexes, that characterize the value of the actually operating infrastructural, intellectual, human, and other intangible constituents, determines the scope of their productive energy (effectiveness) in operating capital, and together with tangible and financial capital - additional synergy power and efficiency of the enterprise potential ("ideal capital").

3. It is offered to conduct evaluation of the intangible capital value and management of the intangible constituent cost of the machine-building enterprise, monitoring and diagnostics of the structural 


\section{Financial management of the enterprise economic potential}

components value of the intangible factors on the basis of the modelled approach according to which the value of "traditional" (verified) intangible assets (K1) is determined by their paid (residual) cost.

4. It is offered to include the index of intellectual-informative capital aggregated on the formalized methodological basis into the financial statements.

\section{References}

1. Yevtukh, O. (2005). Teoriya vartosti cherez pryzmu finansiv [Value theory through the lens of finance]. Finansy Ukrayiny - Finance of Ukraine, 11, 7-20 [in Ukrainian].

2. Pyatnitskiy, D. (2006). Ocenka stoimosti korporaciy Germanii [German corporate valuation]. Mirovaya ekonomika i mezhdunarodnye otnosheniya - World Economy and International Relations, 10, 43-47 [in Russian].

3. Braley, R. \& Myers, S. (1977). Principy korporativnyh finansov [Corporate finance principles]. Moscow: Olimp - Business [in Russian].

4. Doyle, P. (2001). Marketing, oriyentirovannyy na stoimost: Marketingovyye strategii dlya obespecheniya rosta kompanii i uvelicheniya yeye aktsionernoy stoimosti [Value-based marketing: marketing strategies to ensure company growth and increase its shareholder value]. Sankt-Peterburg: Piter [in Russian].

5. Skott, M. (2000). Faktory stoimosti: Rukovodstvo dlya menedzherov po vyyavleniyu rychagov sozdaniya stoimosti [Cost Factors: A guide for managers to identify value leverage]. Moscow: "Olimp-Business" [in Russian].

6. Kouplend, T., Koller, T. \& Murin, D. (2002). Stoimost kompaniy: ocenka i upravleniye [Company value: valuation and management]. Moscow: "Olimp - Business" [in Russian].

7. Damodaran, A. Value Creation and Enhancement: Back to the Future.. Los Angeles: Stern School of Business, 1999.

8. Momot, T. (2006). Vartisno-oriyentovanyy orhanizatsiyno- ekonomichnyy mekhanizm korporatyvnoho upravlinnya aktsionernymy tovarystvamy: teoriya, metodolohiya i praktyka [Value-oriented organizational and economic mechanism of corporate governance of joint stock companies: theory, methodology and practice]. Doctor's thesis. Kharkiv: Kharkiv National Academy of Urban Economics [in Ukrainian].

9. Danko, M. (2005). Formuvannya korporatyvnykh struktur $v$ Ukrayini [Formation of corporate structures in Ukraine]. Ekonomika $i$ prohnozuvannya - Economics and forecasting, 4, 50-65 [in Ukrainian].
10. Yaremko, I., Plekan, M., Kantsir, I. \& Andrejkiv, T. (2018). Informational and financial instruments for evaluation and management of the company's value. Journal of Eastern European and Central Asian Research. 5 (2), 131-139. Retrieved from:: http://ieeca.org/journal/index.php/JEECAR/issue/v iew/15. DOI: http://dx.doi.org/10.15549/ jeecar.v5i2.246

11. Mizhnarodni ta natsional'ni standarty korporatyvnoho upravlinnya: Zbirnyk kodeksiv ta pryntsypiv [International and national corporate governance standards: Codex and Principles Collection]. International Finn. corporation; Project "Corporate Development of Ukraine". Kyiv [in Ukrainian].

12. Rappoport, A. Creating Shareholder Value: The New Standart for Business Performance. New York: The Free Press [in English].

13. Martin, Dzh., \& Petti, V. (2006). VBM upravlinnya, shcho bazuyet'sya na vartosti: Korporatyvna vidpovid revolyutsiyi aktsioneriv [VBM - value based management: the corporate response of the shareholder revolution]. Dnipropetrovsk: Balance Business Bus [in Ukrainian].

14. Chumachenko, M. \& Pankov, V. (2004). Upravlinnya vartistyu kompaniyi na osnovi tsinnisnoho pidkhodu [Value management of a company based on a value approach]. Naukovoteoretychnyy ta informatsiyno-praktychnyy zhurnal Ministerstva finansiv Ukrayiny - Scientifictheoretical and informational and practical journal of the Ministry of Finance of Ukraine, 2, 66-79 [in Ukrainian].

15. Kurochkina, I. (2007). Otsinka vartosti biznesu sub"yektiv hospodaryuvannya (na prykladi metalurhiynykh ta koksokhimichnykh pidpryyemstv) [Estimation of business entities' business value (on the example of metallurgical and coke-chemical enterprises)]. Candidate's thesis. Kharkiv: Kharkiv National Academy of Urban Economics [in Ukrainian].

16. Bugrov, O., \& Bugrova, O. (2009). An algorithm of selecting the pricing model for a construction contract. Eastern-European Journal of Enterprise Technologies, 1(3), 13-21. DOI: https://doi.org/ 10.15587/1729-4061.2019.155779.

17. Savchenko, L. \& Grygorak, M. (2009). Determination of parameters of the stochastic inventory management system in the conditions of economically-based shortage. Eastern-European Journal of Enterprise Technologies, 1(3), 37-46. DOI: https://doi.org/10.15587/1729-4061.2019. 156475 . 